\title{
IMPACT OF MOISTURE CONDITIONS ON EARLY SHRINKAGE OF ORDINARY CONCRETE WITH CHANGING W/C RATIO
}

\author{
JÓZEF JASICZAK ${ }^{1}$, PAWEŁ SZYMAŃSKI ${ }^{2}$, PIOTR NOWOTARSKI, ${ }^{3}$
}

\begin{abstract}
Article presents the results of the effect of humidity on early shrinkage of normal concrete with variable $\mathrm{W} / \mathrm{C}$ ratio. As known for a long time, shrinkage is dependent of many factors. One of them is the $\mathrm{W} / \mathrm{C}$ ratio and the quantity of water which is located in the concrete mix. In article there were discussed changes taking place in the concrete mix, the methods of research and the partial results obtained by the authors of the paper. Shrinkage is a phenomenon well known and studied by various research centers. The total amount of shrinkage may depend on various factors such as humidity, temperature, composition of the concrete mix, the $\mathrm{W} / \mathrm{C}$ ratio, the size of the item. The study was conducted to determine the amount of shrinkage in its early stages. It is very important for concrete floors contractors, precast manufacturers to start at the right time finishing work and prevent the formation of shrinkage cracks.
\end{abstract}

Keywords: concrete, shrinkage, w/c ratio, drying shrinkage,

\section{INTRODUCTION}

Concrete shrinkage problem was raised by several authors, starting from specialists in chemistry and ending with engineers. The development of concrete technology in recent years, the introduction of chemical additives, plasticizers and superplasticizers, mineral additives and production of concrete with high and ultra-high strengths, B. Klemczak [1], M. Kaszyńska [2], T. Zdeb [3], M. Kosior-Kazberuk [4] necessitated the creation of a wider view on the shrinkage of concrete and opened a new field of research. The authors of this publication belong to the group of people dealing with this issue both in cognitive and application terms, for example, for industrial floors localized on the ground. Innovation in the presented results of the study was examining the shrinkage at various stages: the initial shrinkage containing swelling, chemical shrinkage (contraction) and plastic, followed by expansion, and second contraction (shrinkage during drying).

1 jozef.jasiczak@put.poznan.pl

pawel.s.szymanski@put.poznan.pl

3 Corresponding author: Politechnika Poznańska, Instytut Konstrukcji Budowlanych, ul. Piotrowo 5, 60-965 Poznań, e-mail: piotr.nowotarski@put.poznan.pl 


\section{IMPACT OF W/C RATIO AND MOISTURE CONDITIONS ON EARLY SHRINKAGE}

OF CONCRETE

Shrinkage is dependent on many parameters, which include: the W/C ratio, type of aggregate and its amount in the concrete mix, the type and amount of cement, climatic conditions in which the concrete is cured, the type of used addition and mineral admixture. The higher is the $\mathrm{W} / \mathrm{C}$ ratio the bigger is the shrinkage of concrete, which is associated with the amount of water that must be evaporated from the concrete mix. J.J. Brooks [5] demonstrated that shrinkage of hydrated grout is directly proportional to the $\mathrm{W} / \mathrm{C}$ ratio in the range of $0.2-0.6$. At higher values additional water is removed during drying without shrinkage effects. Not without significance is dosing of plasticizers and superplasticizers lowering the water content in the mixture. The primary effect is indirect and relies on the fact that the admixtures can change the water content of the mixture or cement, or both these components, and the combined action of these changes influence the shrinkage effect. The amount and type of cement significantly influences the shrinkage of concrete, but the shrinkage of the cement grout is different from the shrinkage of the concrete. Greater shrinkage of clean grout does not necessarily mean greater shrinkage of concrete made from the same cement. P.C. Aictin [6,7], W. Kurdowski [8], A.M. Neville [9].

With the constant W/C ratio, with increasing amounts of slurry per volume unit, the concrete shrinkage increases. It is connected with a higher content of water in the concrete, and a lower content of the aggregate, whose presence reduces shrinkage. Concrete shrinkage is always much lower than the shrinkage of the cement paste with the same value of $\mathrm{W} / \mathrm{C}$ ratio. It is very important to know if the cement paste hydrates with an external water source or not. When there is no external source of water, in a closed system cement paste dries without weight loss and shrinks. Water present in the thick capillaries, which energy is small, is easy pulled out through the nanopores formed by chemical shrinkage. When the $\mathrm{W} / \mathrm{C}$ ratio of a closed system is high, the initial amount of water is large and the capillary have a large diameter because cement particles initially are far apart. Due to this fact, many grains of cement starts hydration parallel, drying very fine capillaries can lead to tensile stress, which contract laitance. If the hydratation of the slurry with a low $\mathrm{W} / \mathrm{C}$ ratio is carried out in the presence of an external water source, as long as the water phase is continuous meniscus are not formed, and there is no self shrinkage. W. Kurdowski [8], A.M. Neville [9].

While keeping concrete in water or concrete curing in a humidity of about $99 \%$, swelling phenomenon occurs. Swelling of concrete made from cement of standardized chemical composition is mainly due to the phenomenon of adsorption of water by the gel. The water adsorbed by the gel having a large specific surface produces an increase in the internal pressure between the particles that wipes over them on longer distances. At the same time water adsorbed on the surface of the gel reduces its surface energy, which leads to further expansion. 
In 1998-2001, there were conducted in Magnel Laboratory for Concrete Research of Ghent University (Belgium) extensive research on shrinkage of concrete of industrial floors made on the ground. Ratings of concrete shrinkage was carried out in laboratory conditions at a constant temperature and relative humidity as well as in the open space with the real variable environmental conditions P. De Pauw [10].

The study used five types of concrete mixes and one cement CEM III / A 42.5 LA in quantities of $320 \mathrm{~kg}$. To the mixtures there were added superplasticizers at rate of $1.5 \%$ mc.(mass of cement). From the concrete there was made 10 concrete slabs measuring $4.5 \times 4.5 \mathrm{~m}$ and of thickness of $0.15 \mathrm{~m}$ (Slabs were reinforced by mesh $\phi 6$ of jacketed $0.15 \times 0.15 \mathrm{~m}$ ) and $0.13 \mathrm{~m}$ (the last two discs with reinforcement distributed 50/1 mm in an amount of $30 \mathrm{~kg} / \mathrm{m} 3$ ). Shrinkage measurements were performed on samples with dimensions $0.15 \times 0.15 \times 0.60 \mathrm{~m}$ and directly on 10 slabs. For all types of concrete, samples were divided into two groups: some of them were cured for more than two years in a climate chamber with fixed parameters $\left(20^{\circ} \mathrm{C}, 60 \% \mathrm{RH}\right)$, some of them were left on the concrete slabs - samples were influenced by the changing weather conditions. The shrinkage levels were in line with expectations: shrinkage is steadily growing, and the values after 3 days $-0 \mathrm{~mm} / \mathrm{m}$, after 28 days $-0.3 \mathrm{~mm} / \mathrm{m}$, after 300 days $-0.5 \mathrm{~mm}$ / $\mathrm{m}$, later $-0,5$ to $0.6 \mathrm{~mm} / \mathrm{m}$. Shrinkage for all types of concrete, was the same. The same samples exposed to the direct effects of weather had significantly lower shrinkage values (range $+0.1 \mathrm{~mm} / \mathrm{m}$ to $-0,2 \mathrm{~mm} / \mathrm{m}$ ) and the differences between the concrete C1 (320 kg cement without additives) and C4 (375 kg cement, superplasticizer) were significantly higher P. De Pauw [10].

Periodically were observed both the swelling and shrinkage (Figure 1,2) which inspired the authors to model these effects in a climatic chamber and at varying relative humidity (from 35\% to almost $99 \%$ ).

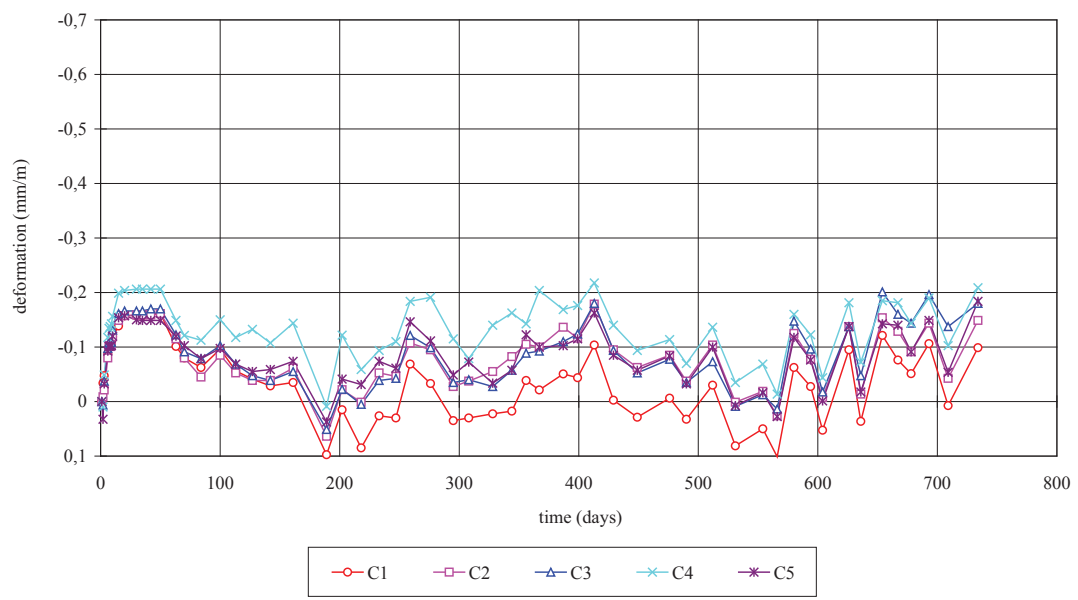

Fig. 1. Prismatic outside storage test specimens and theirs shrinkage inspection 


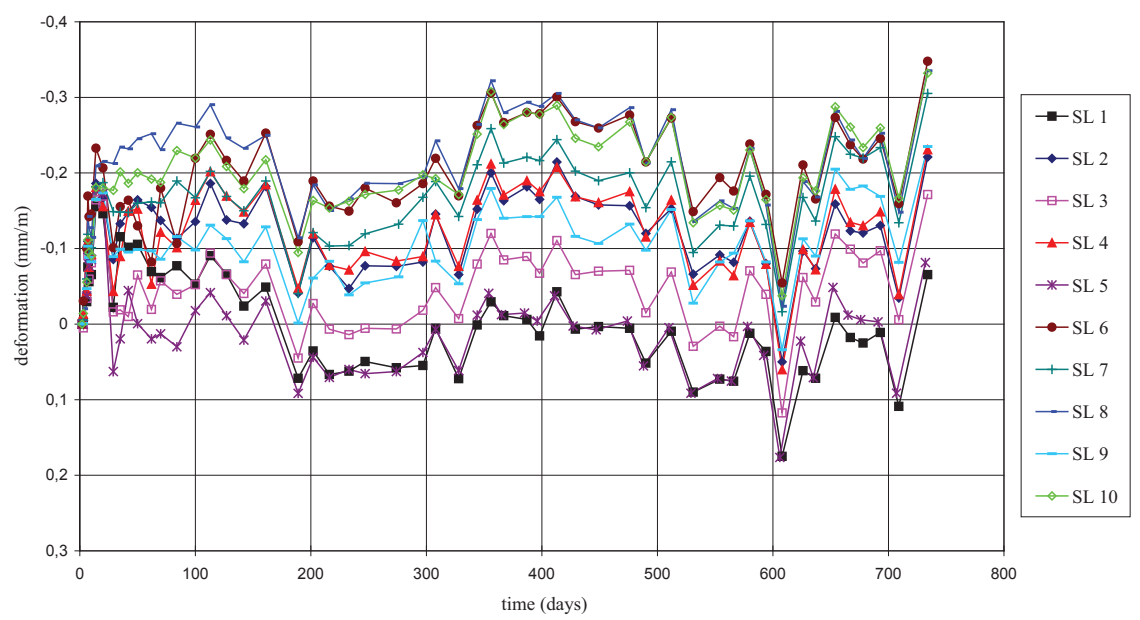

Fig. 2. Average deformations measured at the slab surfaces (outside storage)

\section{CONCRETE SHRINKAgE TEST STAND DESCRIPTION}

Concrete shrinkage is a phenomenon scientifically well-known and well-documented. It is closely associated with physicochemical processes extending in the cement paste. Shrinkage of concrete is called the reduction of the volume of concrete resulting from the loss of water by drying. Previous measurements of shrinkage concerned hardened grouts (mortar, concrete) and was carried out from 1-2 days of hardening. New quality of measurements have been created by experiments of S. Miyazawa and E. Tazawa of 1995 [11,12], and later T. Nawa and T. Horita [13] and the authors of the years 2004 to 2012, J. Jasiczak, P. Szymański [14, 15, 16], wherein the shrinkage of concrete is measured from the time of earning ingredients with water, initially using sensors with metric scale and later electronically.

Author's research of shrinkage include also studies from mixing the ingredients with water. This allows to take into account the different phases of shrinkage: from plastic shrinkage, chemical, autogenous to drying shrinkage. Previous studies of concrete shrinkage did not take into account wider phenomenon of shrinkage of the concrete mix from the point of mixing with water, their value was not measured with such accuracy and frequency as it was done by authors. Metric readers was changed to potentiometric sensors which measure accurately the current voltage in the connection continuously by sensors placed in the concrete. The test stand consists of: measuring apparatus of Magelab, environmental chamber, the bus terminal, assist device - computer, including equipment, uninterruptible power supply, sensor calibrator micrometer, potentiometric sensors for the measurement of shrinkage, temperature sensors, humidity sensors. Kit prevents the need for time consuming measurement using displacement sensors with the possibility of advanced computer processing of collected data. 
Changing the length of the sample result in a change of the parameters of the electric current which, after the calibration, are processed automatically into units of length. Measurement using the sensor so constructed has many advantages. First of all, it is possible to measure the shrinkage of the concrete immediately after mixing components of a mixture with water. There are possible measurements of chemical shrinkage, plastic shrinkage and shrink of hydratate grout. Reading of the shrinkage may be made every two seconds, and the results are recorded digitally. The disadvantage of set-up is unusual sensitivity to changes in ambient temperature and relative humidity, so the result should be corrected by introducing a factor related to external parameters. Concrete samples are placed in a climate chamber, the temperature and relative humidity in the chamber is controlled by a built-in microcomputer, which keeps the value on a constant, predetermined level during the entire cycle. Such conditions can be maintained for several months and can be changed at any time. Test samples for shrinking have dimensions: 250x100x20 mm (length, width, height). Measuring length $1=190 \mathrm{~mm}$ is entrenched nature of the attachment of sensors contraction (Figure 3).

The testing potentiometric sensors are used to measure voltage of the current flowing continuously through the detectors. Change of the length of the sample result in change of the parameters of the electric current which, after the calibration are processed into unit of length. The results are recorded by the program numerically. Shrinkage measurement is carried out in Volts. To change it on the unit of length scaling of displacement sensors was performed. The kit also includes measurement software ATEWIN so that it is possible to store, process and processing data in order to determine the amount of shrinkage of concrete (Figure 4).

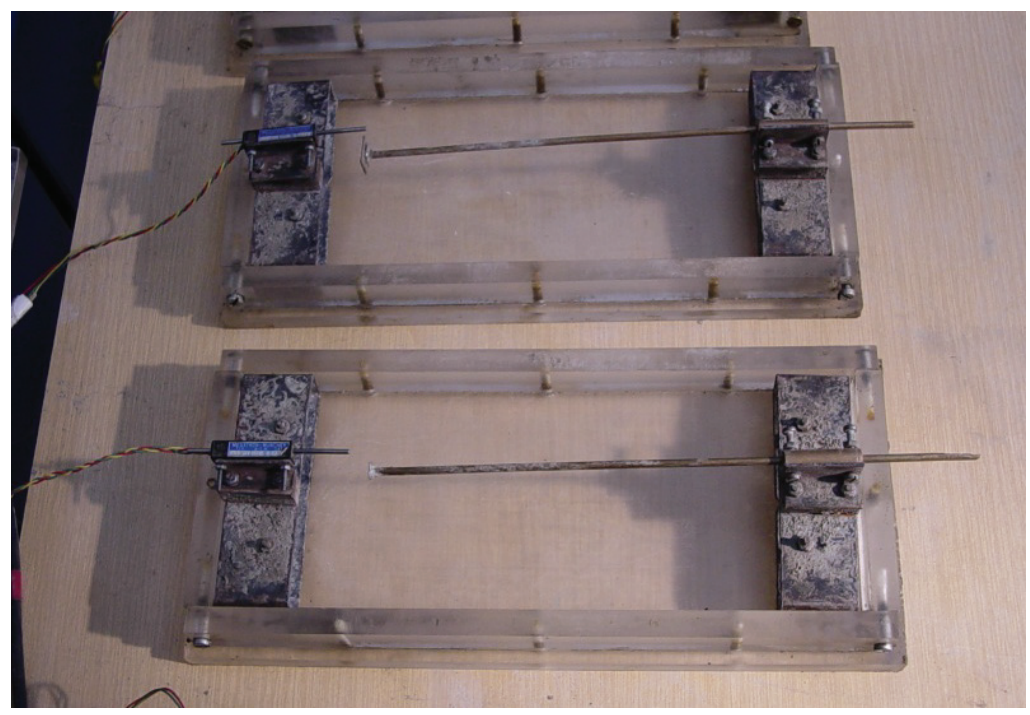

Fig. 3. Forms for concrete shrinkage testing 


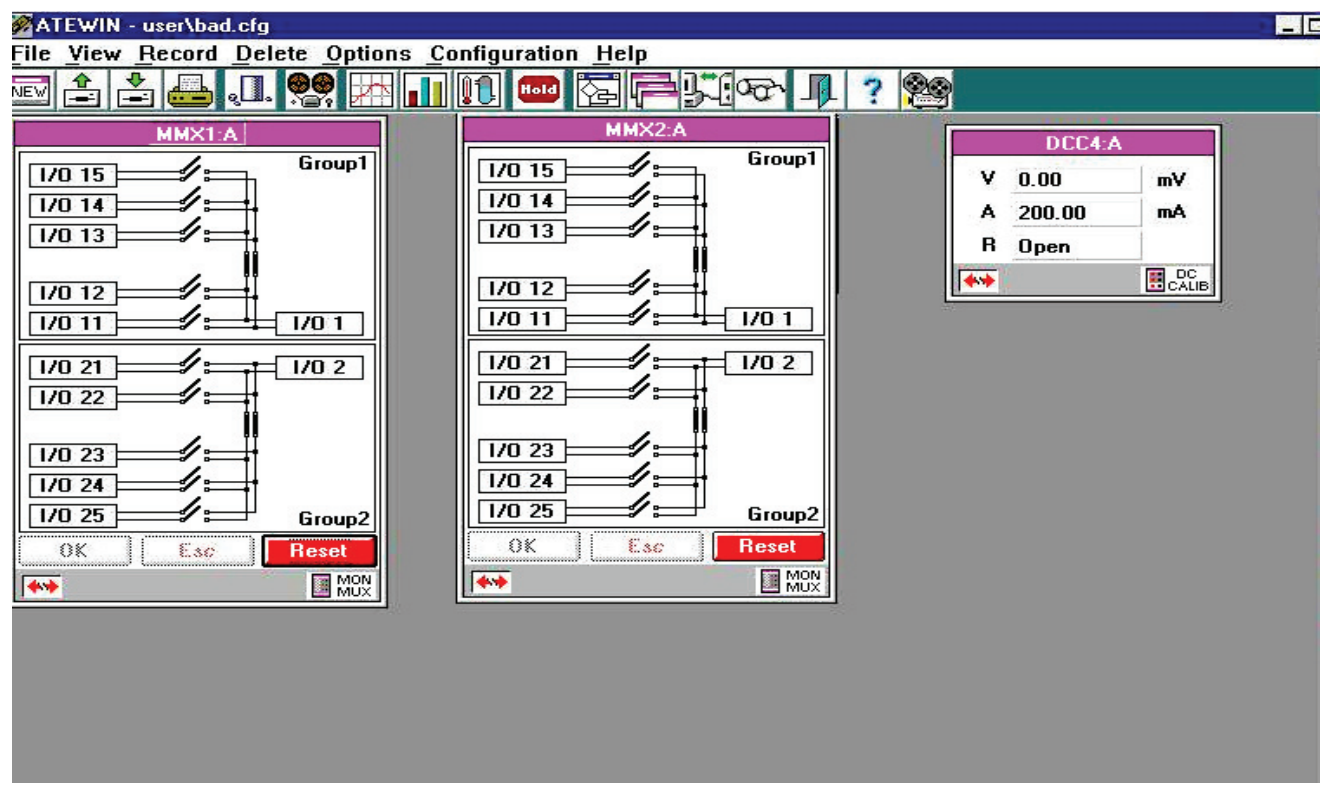

Fig. 4. ATEWIN software

4. Results AND ANALYSIS OF THE SHRINKAGE OF CONCRETE

\subsection{CONCRETE AND CONCRETE MIX}

Shrinkage tests were carried out using cement CEM I 42.5 R HSR NA of a specific surface area $2927 \mathrm{~cm}^{2} / \mathrm{g}$ according to Blaine, a very low $\mathrm{C}_{3} \mathrm{~A}$ content and a low alkali content (Table 1) Amount of cement in all mixtures was constant, the percentage of aggregates was also constant at the level of:

$33 \%$ sand $0-2 \mathrm{~mm}$,

$36 \%$ aggregate $2-8 \mathrm{~mm}$,

$31 \%$ aggregate $8-12 \mathrm{~mm}$.

The only variable parameter was $\mathrm{W} / \mathrm{C}$ ratio which was: $0.35,0.45,0.55$. Composition of concrete mixtures and compressive strengths are given in Table 2. During the study of shrinkage samples were stored in a climatic chamber where constant conditions were prevailed for the whole study. Samples were kept at $20^{\circ} \mathrm{C}$, relative humidity of $35 \%, 85 \%$, and closed in foil(relative humidity about $99 \%$ ). There were also evaluated the samples initially stored in a climate chamber, for 24 hours in foil and after removing foil saying in the climate chamber in proper relative humidity. Figures 4, 5, 6 shows time of the binding and the compressive strength of cement. 
The chemical composition and properties of cement I 42,5R HSR NA

\begin{tabular}{|c|c|}
\hline The specific surface area by Blaine & $2927 \mathrm{~cm}^{2} / \mathrm{g}$ \\
\hline Initial setting time & $240 \mathrm{~min}$ \\
\hline End of binding & $360 \mathrm{~min}$ \\
\hline The insoluble in $\mathrm{HCl}$ & $0,27 \%$ \\
\hline Ignition loss & $0,8 \%$ \\
\hline $\mathrm{CaO}$ & $64,22 \%$ \\
\hline $\mathrm{SiO}_{2}$ & $21,36 \%$ \\
\hline $\mathrm{Al}_{2} \mathrm{O}_{3}$ & $4,11 \%$ \\
\hline $\mathrm{Fe}_{2} \mathrm{O}_{3}$ & $5,36 \%$ \\
\hline $\mathrm{SO}_{3}$ & $2,02 \%$ \\
\hline $\mathrm{MgO}$ & $1,16 \%$ \\
\hline $\mathrm{Cl}$ & $0,004 \%$ \\
\hline $\mathrm{Na}_{2} \mathrm{O}_{\text {eqv }}$ & $0,52 \%$ \\
\hline $\mathrm{C}_{3} \mathrm{~S}$ & $56,81 \%$ \\
\hline $\mathrm{C}_{2} \mathrm{~S}$ & $18,36 \%$ \\
\hline $\mathrm{C}_{3} \mathrm{~A}$ & $1,78 \%$ \\
\hline $\mathrm{C}_{4} \mathrm{AF}$ & $16,31 \%$ \\
\hline
\end{tabular}

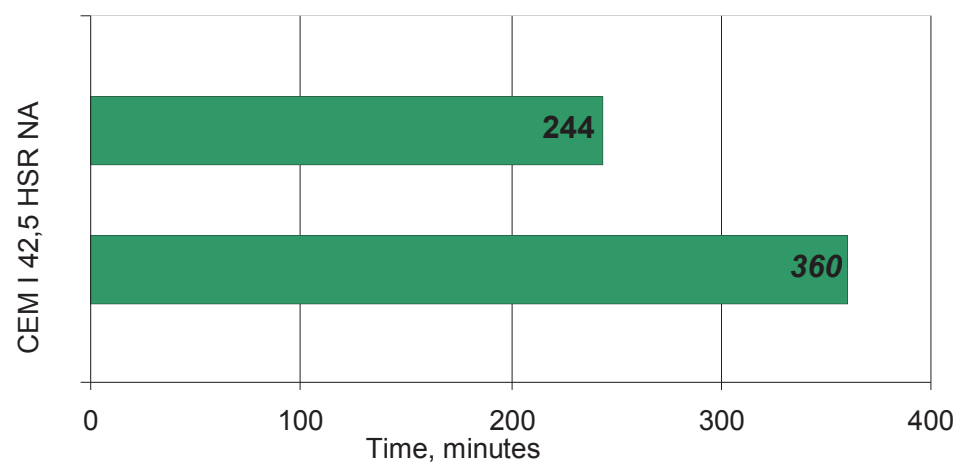

Fig. 5. Beginning and ending of cement binding 
Table 2.

Composition of concrete mixtures and 28 days compressive strength

\begin{tabular}{|l|c|c|c|}
\hline & $\mathrm{W} / \mathrm{C}=0,35$ & $\mathrm{~W} / \mathrm{C}=0,45$ & $\mathrm{~W} / \mathrm{C}=0,55$ \\
\hline Cement & $400 \mathrm{~kg}$ & $400 \mathrm{~kg}$ & $400 \mathrm{~kg}$ \\
\hline Water & $140 \mathrm{~L}$ & $180 \mathrm{~L}$ & $220 \mathrm{~L}$ \\
\hline Sand $0-2 \mathrm{~mm}$ & $623 \mathrm{~kg}$ & $588 \mathrm{~kg}$ & $553 \mathrm{~kg}$ \\
\hline Gravel $2-8 \mathrm{~mm}$ & $678 \mathrm{~kg}$ & $641 \mathrm{~kg}$ & $604 \mathrm{~kg}$ \\
\hline Gravel $8-16 \mathrm{~mm}$ & $584 \mathrm{~kg}$ & $551 \mathrm{~kg}$ & $519 \mathrm{~kg}$ \\
\hline Compressive strength & $44,0 \mathrm{MPa}$ & $42,1 \mathrm{MPa}$ & $22,4 \mathrm{MPa}$ \\
\hline
\end{tabular}

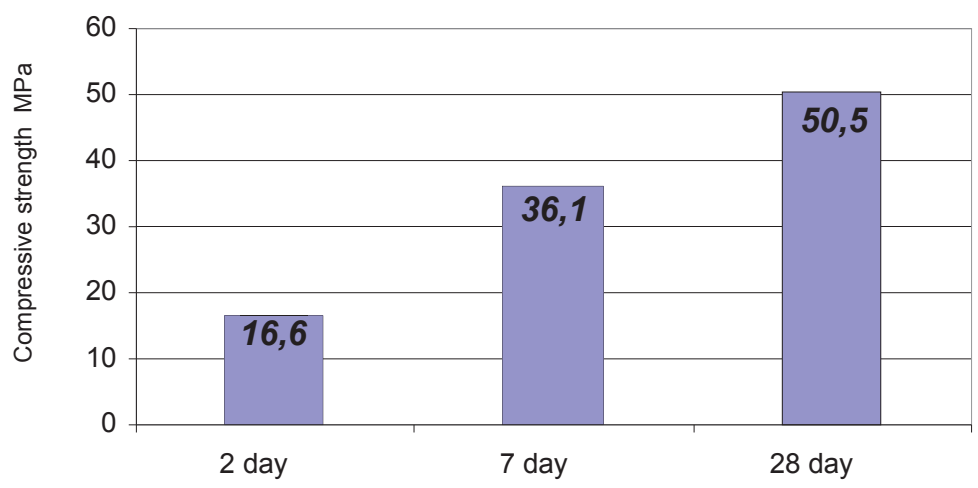

Fig. 6. Compressive strength of cement

\subsection{The COURSE AND RESULTS OF THE RESEARCH-CONCRETE SHRINKAGE}

During the shrinkage test samples were stored in a climatic chamber in which constant conditions prevailed throughout the test cycle. Samples were kept at $20^{\circ} \mathrm{C}$, relative humidity of $35 \%, 85 \%$, and closed in foil(relative humidity almost $99 \%$ ). Results are given in 3 groups. The first group shows the dependence of linear shrinkage - time for concrete with a constant $\mathrm{W} / \mathrm{C}$ ratio cured in three intervals of humidity. The relationships are shown in Figure 7 to 9.

In the second group sample of $\mathrm{W} / \mathrm{C}$ ratio $=0.35,0.45$ and $0.55 \mathrm{kept}$ in the chamber in the foil were drawn after 24 hours and still left in the chamber at $35 \%$ relative humidity. The samples showed initial swelling and later shrinkage increased in proportion to the increasing $\mathrm{W} / \mathrm{C}$ ratio (Figure. 10).

In the third group, measurement results are summarized also in the system linear shrinkage - time for concrete with variable $\mathrm{W} / \mathrm{C}$ ratio but cured at three different periods of moisture. The results are shown in Figures 11, 12, 13. 
concrete shrinkage w/c 0,55

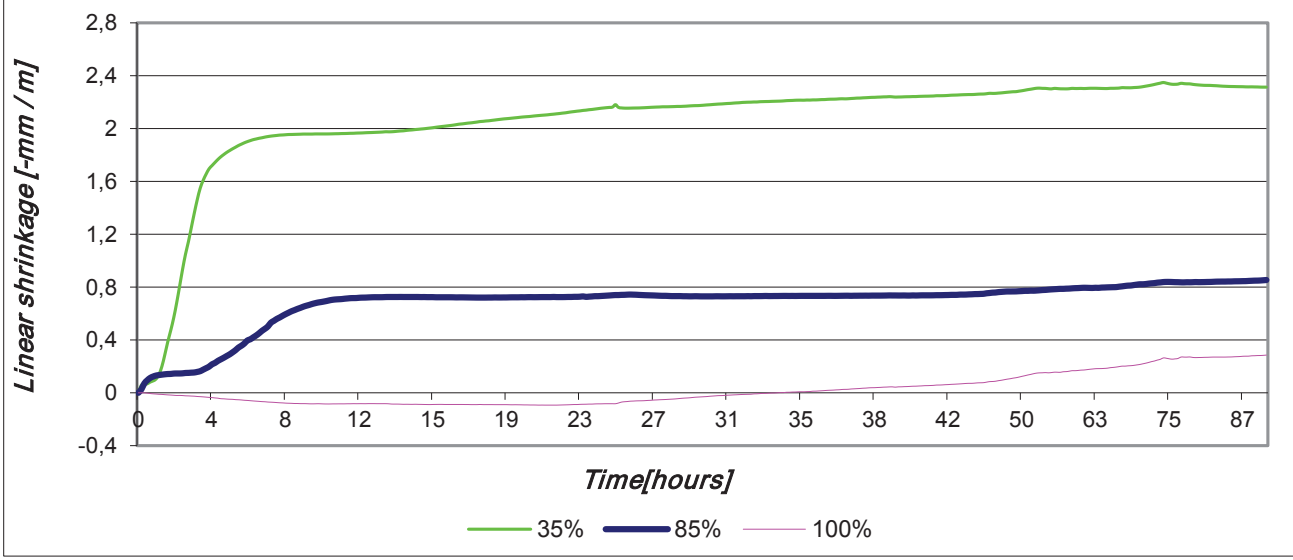

Fig. 7. A shrinkage with $\mathrm{W} / \mathrm{C}$ ratio $=0.55$ for various surroundings relative humidity

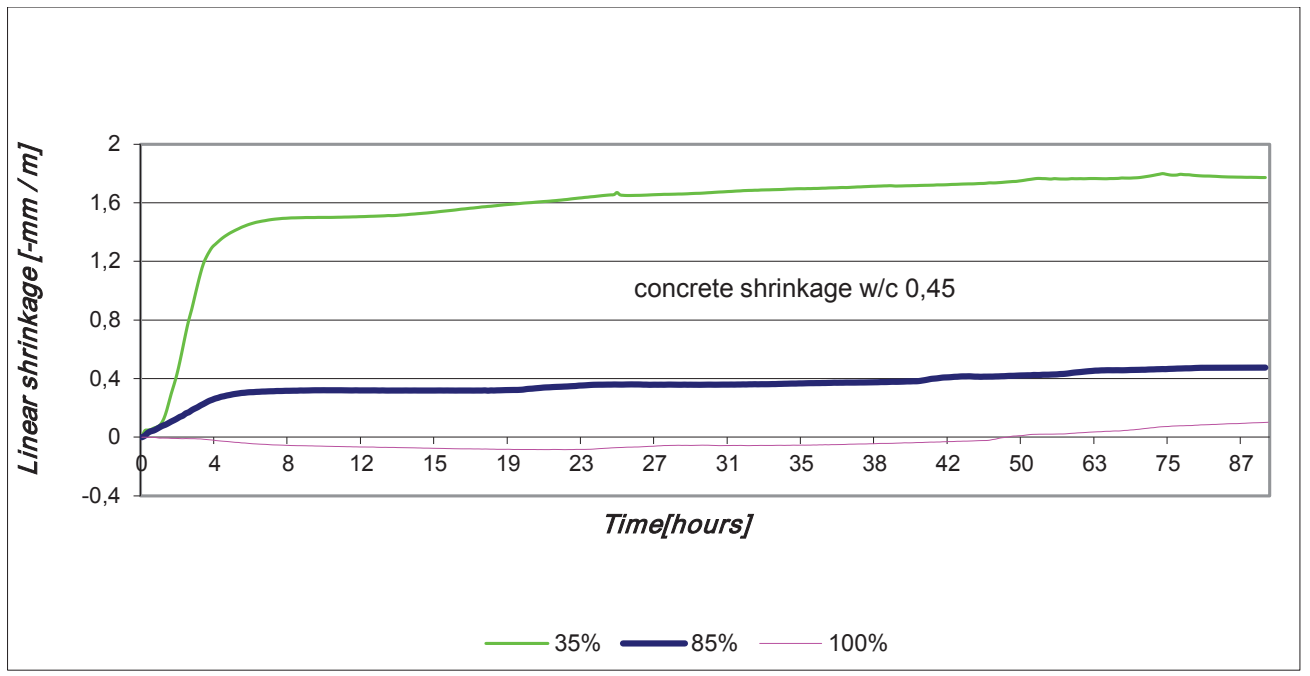

Fig. 8. A shrinkage with $\mathrm{W} / \mathrm{C}$ ratio $=0.45$ for various surroundings relative humidity 


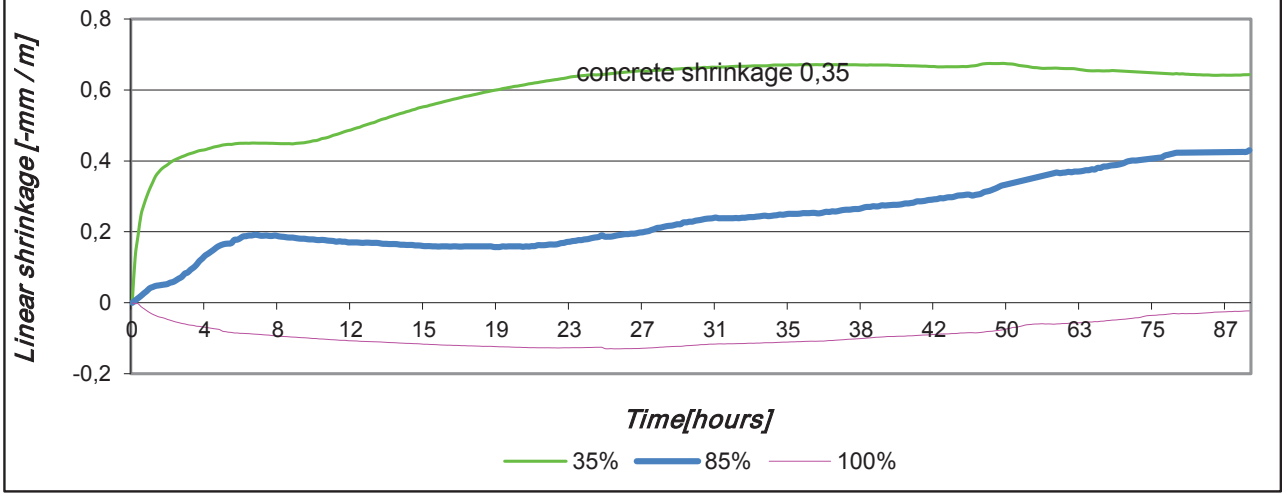

Fig. 9. A shrinkage with $\mathrm{W} / \mathrm{C}$ ratio $=0.35$ for various surroundings relative humidity

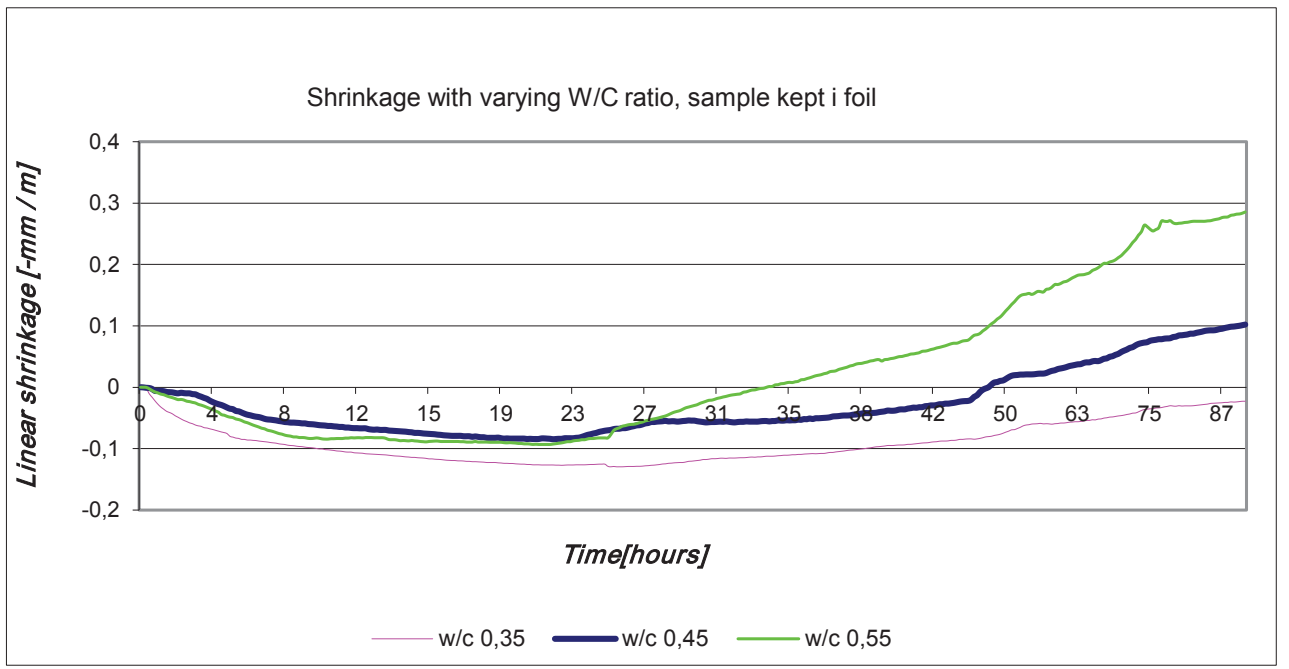

Fig. 10. The swelling index of concrete with different $\mathrm{W} / \mathrm{C}$ ratio in $99 \%$ humidity for 24 hours, and humidity of $35 \%$ for the rest of the test cycle 


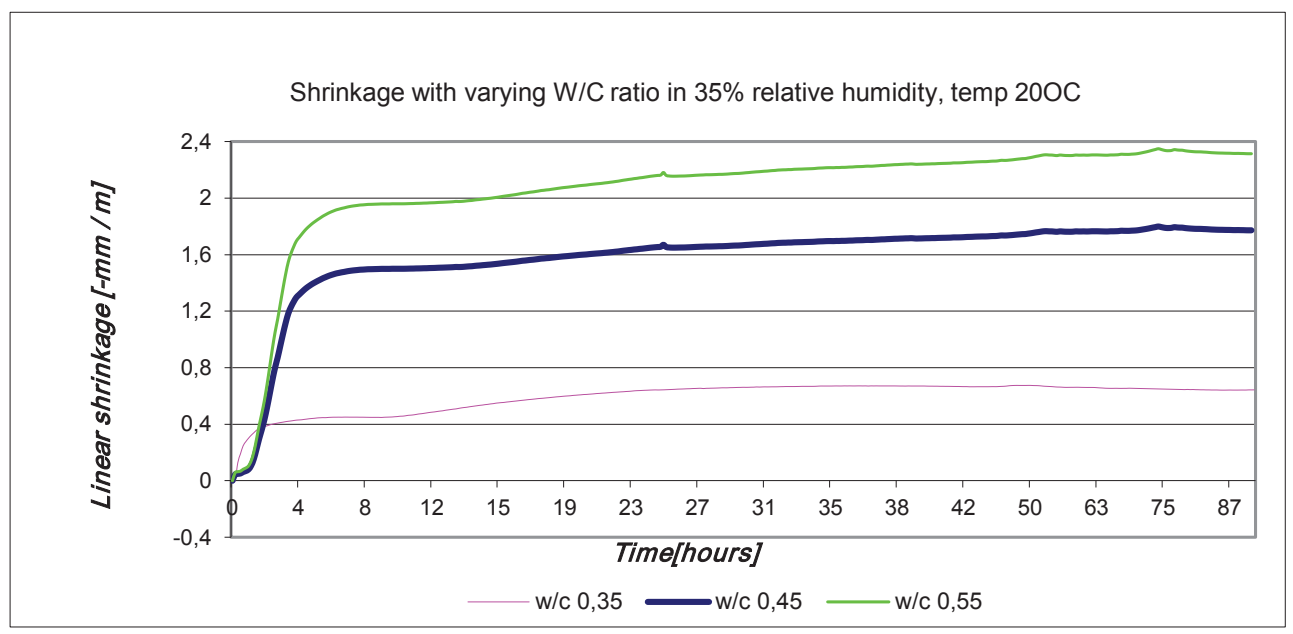

Fig. 11. Shrinkage with varying $\mathrm{W} / \mathrm{C}$ ratio in $35 \%$ relative humidity

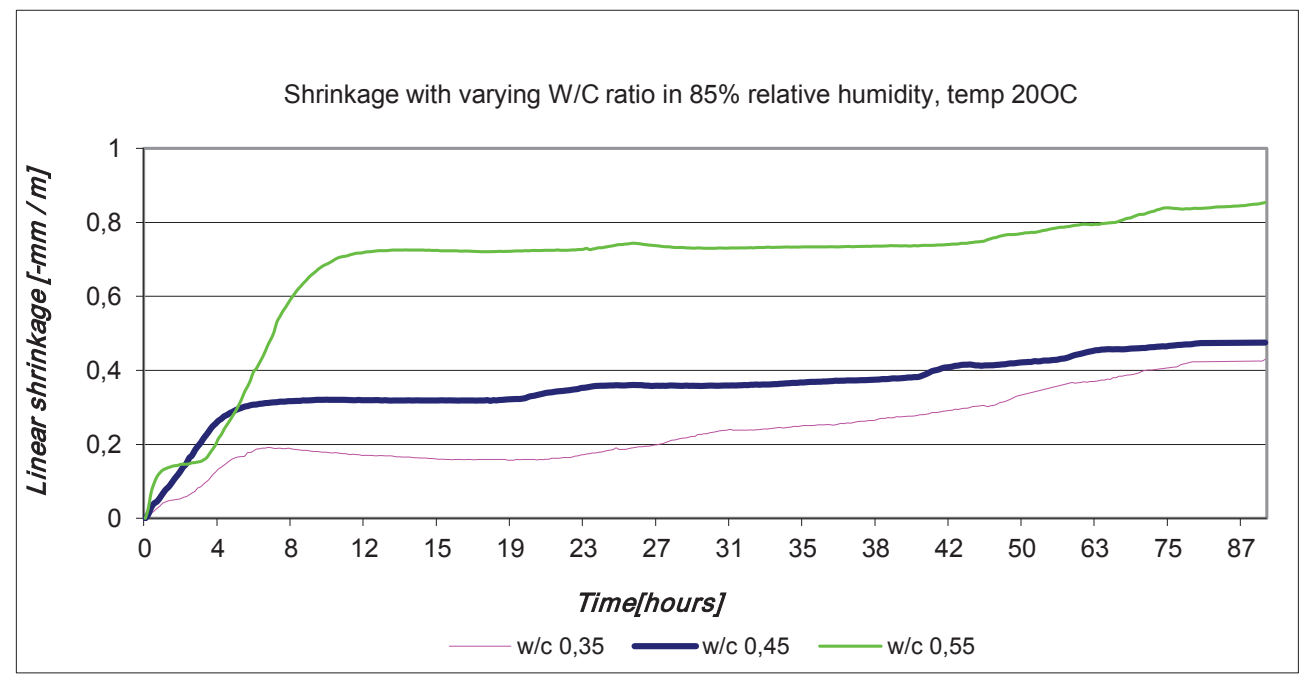

Fig. 12. Shrinkage with varying $\mathrm{W} / \mathrm{C}$ ratio in $85 \%$ relative humidity 


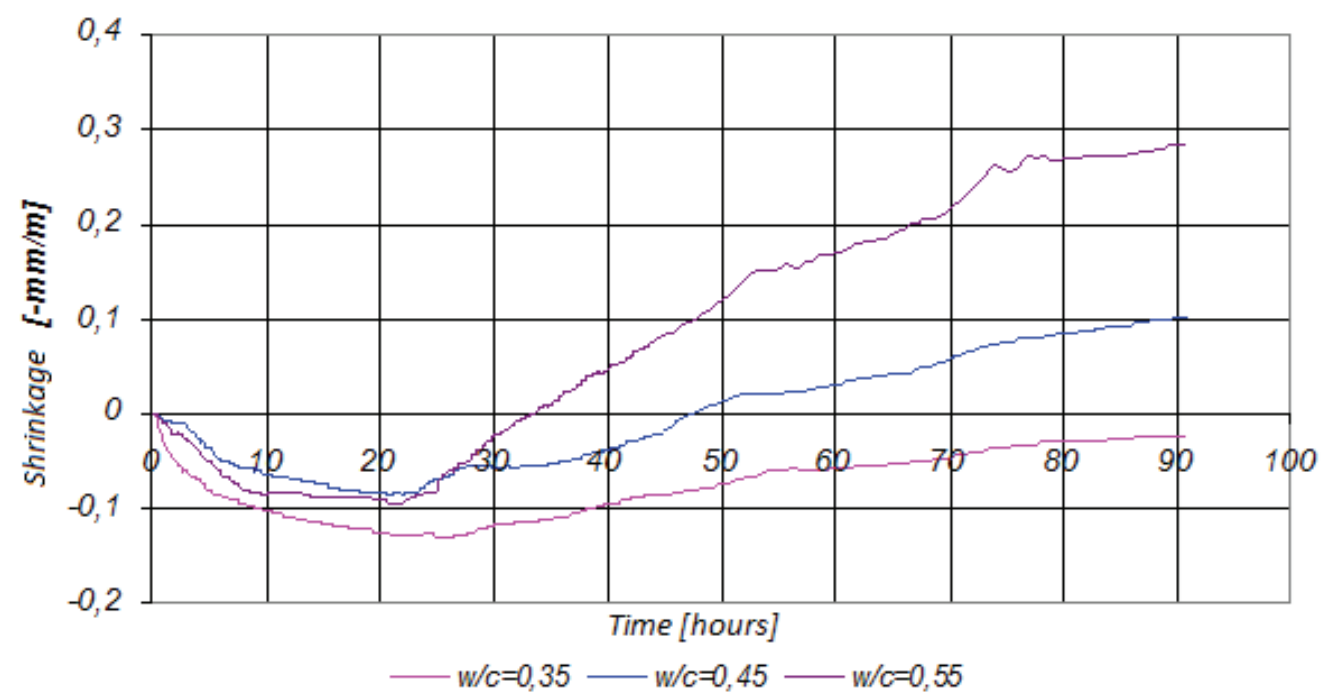

Fig. 13. Concrete shrinkage with cement CEM I 42,5 HSR NA with changing W/C Ratio. Samples stored in temperature of $20^{\circ} \mathrm{C}$ and relative humidity $=99 \%$ for 24 , later $\mathrm{RH}=35 \%$

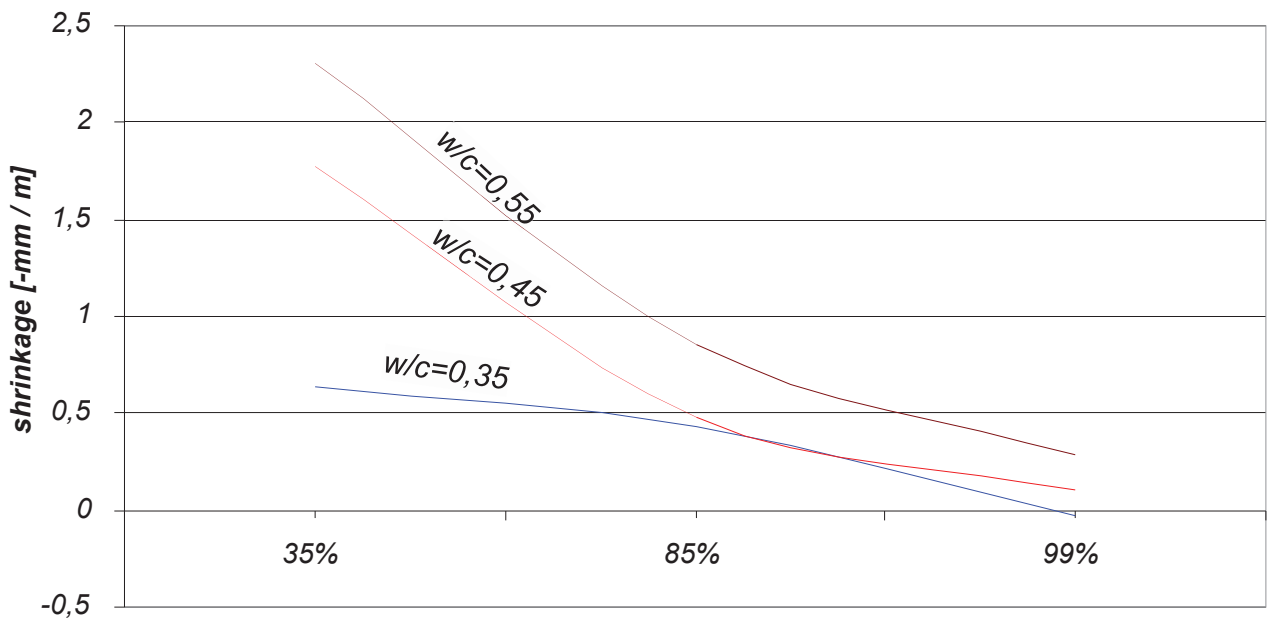

humidity

Fig. 14. The relationship between the $\mathrm{W} / \mathrm{C}$ ratio and the shrinkage for various moisture 


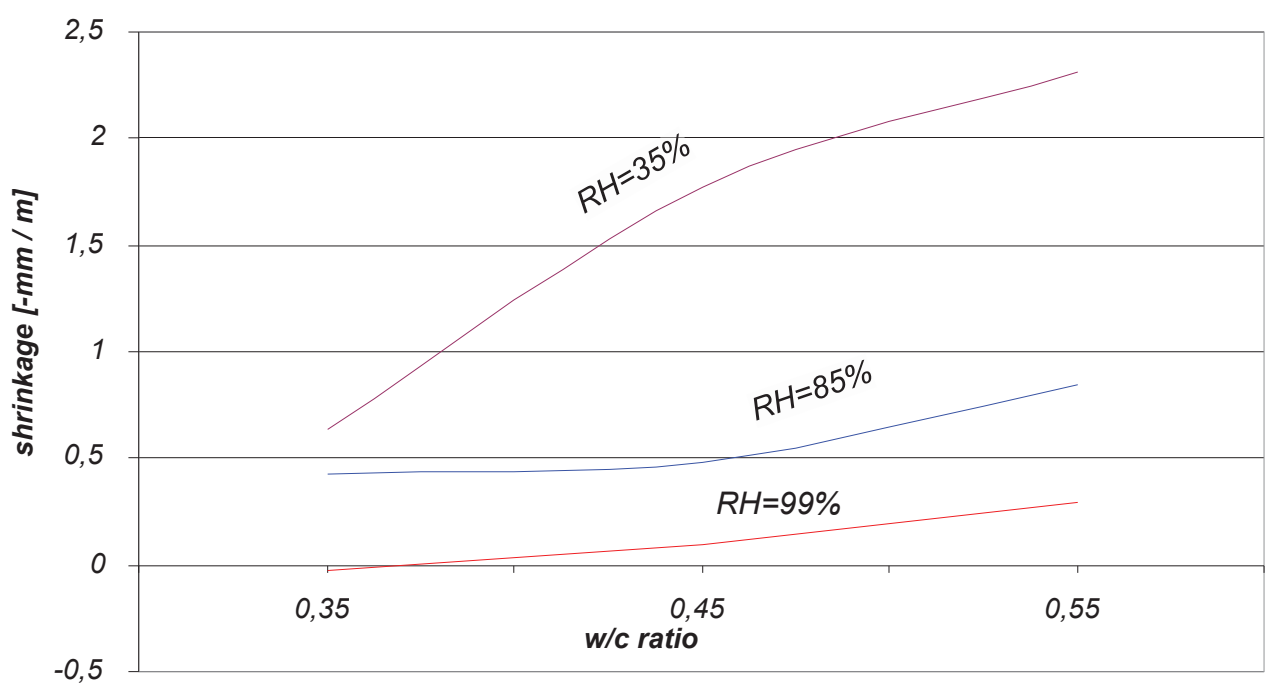

Fig. 15. The relationship between moisture and shrinkage

\subsection{ANALYSis of the test RESUlts}

The study shows that the $\mathrm{W} / \mathrm{C}$ ratio significantly affects the volume of shrinkage, regardless of the humidity. In Tables 3 and 4, there are given values of early shrinkage where the variable parameter was the size of $\mathrm{W} / \mathrm{C}$ ratio.

Table 3.

Shrinkage values with changing $\mathrm{W} / \mathrm{C}$ ratio, concrete stored in $35 \% \mathrm{RH}$ and a temperature of $20^{\circ} \mathrm{C}$, first result after $10 \mathrm{~min}$ from producing concrete

\begin{tabular}{|c|c|c|c|c|c|c|}
\hline \multirow[b]{2}{*}{$\begin{array}{l}\text { phases of } \\
\text { shrinkage }\end{array}$} & \multicolumn{2}{|c|}{ Plastic shrinkage } & \multirow{2}{*}{$\begin{array}{c}\text { Expansion } \\
\text { time } \\
\text { "n"-“m" } \\
\text { [hours] }\end{array}$} & \multicolumn{2}{|c|}{ Drying shrinkage } & \multirow[b]{2}{*}{$\begin{array}{l}\text { total shrinkage } \\
\text { after } 100 \text { hours }\end{array}$} \\
\hline & $\begin{array}{c}\text { time } \\
0-“ n " \\
\text { [hours] }\end{array}$ & $\begin{array}{l}\text { shrinkage } \\
{[-\mathrm{mm} / \mathrm{m}]}\end{array}$ & & $\begin{array}{c}\text { time } \\
\text { "m"-100 } \\
{[\text { hours] }}\end{array}$ & $\begin{array}{l}\text { shrinkage } \\
{[-\mathrm{mm} / \mathrm{m}]}\end{array}$ & \\
\hline $\mathrm{w} / \mathrm{c}=0,35$ & $0-4,5$ & 0,44 & $4,5-9,4$ & $9,4-100$ & 0,19 & 0,64 \\
\hline $\mathrm{w} / \mathrm{c}=0,45$ & $0-6,6$ & 1,48 & $6,6-11,7$ & $11,7-100$ & 0,27 & 1,77 \\
\hline $\mathrm{w} / \mathrm{c}=0,55$ & $0-7,0$ & 1,94 & $7,0-12,1$ & $12,1-100$ & 0,34 & 2,31 \\
\hline
\end{tabular}

The presented results show the relationship between the size of $\mathrm{W} / \mathrm{C}$ ratio and the shrinkage of concrete, and the relationship between the moisture in which concrete is stored and the $\mathrm{W} / \mathrm{C}$ ratio on the size of the early shrinkage. The figures 14 and 15 show the two dependencies. 
Table 4.

Shrinkage values with changing W/C ratio, concrete stored in $85 \% \mathrm{RH}$ and a temperature of $20^{\circ} \mathrm{C}$, first result after $10 \mathrm{~min}$ from producing concrete

\begin{tabular}{|c|c|c|c|c|c|c|}
\hline \multirow[b]{2}{*}{$\begin{array}{l}\text { phases of } \\
\text { shrinkage }\end{array}$} & \multicolumn{2}{|c|}{ Plastic shrinkage } & \multirow{2}{*}{$\begin{array}{c}\text { Expansion } \\
\text { time } \\
\text { "n"-"m" } \\
\text { [hours] }\end{array}$} & \multicolumn{2}{|c|}{ Drying shrinkage } & \multirow[b]{2}{*}{$\begin{array}{l}\text { total shrinkage } \\
\text { after } 100 \text { hours }\end{array}$} \\
\hline & $\begin{array}{c}\text { time } \\
0-“ n " \\
\text { [hours] }\end{array}$ & $\begin{array}{l}\text { shrinkage } \\
{[-\mathrm{mm} / \mathrm{m}]}\end{array}$ & & $\begin{array}{c}\text { time } \\
\text { "m"-100 } \\
\text { [hours] }\end{array}$ & $\begin{array}{l}\text { shrinkage } \\
{[-\mathrm{mm} / \mathrm{m}]}\end{array}$ & \\
\hline $\mathrm{w} / \mathrm{c}=0,35$ & $0-6,4$ & 0,19 & $6,4-20,3$ & $20,3-100$ & 0,27 & 0,43 \\
\hline $\mathrm{w} / \mathrm{c}=0,45$ & $0-7,0$ & 0,31 & $7,0-19,5$ & $19,5-100$ & 0,15 & 0,48 \\
\hline $\mathrm{w} / \mathrm{c}=0,55$ & $0-11,5$ & 0,15 & $11,5-21,2$ & $21,2-100$ & 0,13 & 0,85 \\
\hline
\end{tabular}

\section{Conclusions}

5.1. Constructed by the authors of the paper test stand for continuous registration of the linear shrinkage of the concrete, immediately after its production, proved to be an efficient tool for the quantitative assessment of these processes. Adopted dimensions 20x100x $250 \mathrm{~mm}$ concrete samples made it possible to study the standard concrete mix of the grain size of $12 \mathrm{~mm}$. One could increase the thickness of the sample into a $40 \mathrm{~mm}$ and use aggregate of size of $20 \mathrm{~mm}$ but there is a fear of failure of uniformly humidity filed at the height of the concrete cross-section and thereby to obtain different shrinkage deformation. Adjustable frequency measurements from two seconds to several minutes allows the precision of the measurement depending on the phase of contraction .

5.2. Research on shrinkage deformations during drying made in Magnel Laboratory demonstrated their high volatility, depending on the environmental conditions (the same deformation of the concrete from 0.2 to $-0.2 \mathrm{~mm} / \mathrm{m}$ ). Studies on the flooring slabs with dimensions $4,5 \times 4,5 \mathrm{~m}$ performed cyclically using geodetic techniques and using dial gauges on the beams. It is not known whether extreme behaviors were accurately determined. Author's apparatus enables continuous measurement of the deformation with not only obtaining extreme shrinkage values, but also designate the time intervals of occurrence .

5.3. Satisfactory data for the study of the shrinkage and for the purpose of application are given in Tables 3 and 4. The tables include intervals of particular phases of contraction and characteristic shrinkage values for them. The first phase of the contraction takes 4.5 hours, and even up to 11.5 hours, depending on the $\mathrm{W} / \mathrm{C}$ ratio and humidity conditions. Contraction of this phase is the largest and ranges from 0.15 to $1.94 \mathrm{~mm} / \mathrm{m}$. Time of expansion is also variable and ranges from a few to several hours, and the average contraction in this period is almost close to 0 . Such a "calming" of concrete is used by cement floor contractors, scuffing the surface and performing apparent expansion joints. After this period, the second contraction is observed, i.e. drying shrinkage, which receives a much lower level than plastic shrinkage (range 0.13 to $0.34 \mathrm{~mm} / \mathrm{m}$ ). The total 
shrinkage of young concrete is very large and is not acceptable for the designers and contractors of construction. Hence the recommendation for production of concrete mixes with low $\mathrm{W} / \mathrm{C}$ ratio and intensive water care or the creation of conditions to reduce evaporation of water from the maturing concrete (protective films, sprayers, etc.).

5.4 Laboratory work confirmed all the known dependence between $\mathrm{W} / \mathrm{C}$ ratio and shrinkage like: the higher the $\mathrm{W} / \mathrm{C}$ ratio, the greater the value of the total contraction of the concret; the higher the $\mathrm{W} / \mathrm{C}$ ratio, the greater duration of the expansion; plastic shrinkage duration depends on the size of the $\mathrm{W} / \mathrm{C}$ ratio and humidity conditions in which concrete is stored; plastic shrinkage of concrete is higher for concrete stored in the lower humidity, for humidity of $35 \%$, the higher is the $\mathrm{W} / \mathrm{C}$ ratio, the drying shrinkage is greater, for humidity of $85 \%$ this relationship is reversed; drying shrinkage increased with the increase of the $\mathrm{W} / \mathrm{C}$ ratio. With the increase of humidity relationship was becoming reversed; the lower the $\mathrm{W} / \mathrm{C}$ ratio, the larger swelling phenomenon of concrete stored in the foil, but when the sample was taken out of foil the drying shrinkage was always the same irrespective of the moment of taking out.

\section{LiTERATURE:}

1. B. KLemCZAK, Mechanical properties of young concrete-experiments and modeling, Archives of Civil Engineering, LIII, 1, 2007, 57-73

2. M. KASZYŃSKa, Effect of temperature on properties of fresh self-consolidating concrete, Archives of Civil Engineering, LII, 2, 2006, 277-287

3. T. ZDEB, J. ŚLIWIŃSKI, The influence of selected material and technological factors on mechanical properties and microstructure of reactive powder concrete (RPC), Archives of Civil Engineering, LVII, 2, 2011, 227-246

4. M. Kosior-Kazberuk, D. Józwiak-NiedzwiedzKa, Influence of fly ash from co-combustion of coal and biomass on scaling resistance of concrete, Archives of Civil Engineering, LVI, 3, 2010, 239-254

5. J.J. BRooks, Influence of mix proportions, plasticizers and superplasticizers on creep and drying shrinkage of concrete. Magazine of Concrete Resarch. Vol. 41, 148, 1989,145-153.

6. P.C. Aictin, P.C, Trwały wysokowartościowy beton - sztuka i wiedza. Materiały Konferencji: Dni Betonu - tradycja i nowoczesność. Szczyrk 2002, 7-36.

7. P.C. Aictin P.C., Hydratacja cementu portlandzkiego widziana oczyma inżyniera budownictwa. Cement Wapno Beton, 3, 2003, 115-130.

8. W. KuRdowski, Chemia cementu, PWN Warszawa 1991.

9. A.M. Neville, Properties of concrete, London 1996.

10. P. De Pauw, G. De Schutter, L. Taerwe, Concrete slabs on grade: behavior under environmental conditions. International Conference: Creep, Shrinkage and Durability Mechanics of Concrete and other Quasi - Brittle Materials. Elsevier Science Ltd. 2001, 379-384.

11. E. Tazawa, S. Miyazawa, Influence of cement and admixture on autogenous shrinkage of cement paste. Cement and Concrete Research. Vol. 25, 2, 1995, 288-292.

12. E. Tazawa, S. Miyazawa, Autogenous shrinkage and drying shrinkage of high strength concrete. $5^{\text {th }}$ international Sympisium on Utylization of High Strength, High Performance Concrete. Sandefiord, Norway, 1999, 1254-1263.

13. T. Nawa, T. Horita, A mechanism of autogenous shrinkage of cementitious materials. Cement Combinations for Durable Concrete. Dundee 2005, 425-434. 
14. J. Jasiczak, P. Szymański, Dobór cementu w aspekcie zjawisk wczesnego skurczu betonu, XIX Konferencja Naukowo-Techniczna Jadwisin 2004, s. 271-278.

15. J. JASICZAK, P. SzYMAnski, Influence of different kinds of cement on early shrinkage of concrete. Cement Combinations for Durable Concrete. Dundee 2005, 399-406.

16. J. JASICZAK, P. SzYMAŃSki, Wczesny skurcz betonu o zmiennym wskaźniku w/c, modyfikowanego domieszkami chemicznymi i dodatkami mineralnymi. Materiały Konferencji: Dni Betonu - tradycja i nowoczesność, 2012, 561-568.

Received: 16.09 .2013

Revised: 08.06.2014 